\title{
Purification and Characterization of a Mitogenic Lectin from Cephalosporium, a Pathogenic Fungus Causing Mycotic Keratitis
}

\author{
Nagaraja N. Nagre, ${ }^{1}$ Vishwanath B. Chachadi, ${ }^{1}$ Sachin M. Eligar, ${ }^{1}$ C. Shubhada, ${ }^{1}$ \\ Radha Pujari, ${ }^{2}$ Padma Shastry, ${ }^{2}$ Bale M. Swamy, ${ }^{1}$ and Shashikala R. Inamdar ${ }^{1}$ \\ ${ }^{1}$ Department of Biochemistry, Karnatak University, Dharwad 580 003, Karnataka, India \\ ${ }^{2}$ National Center for Cell Sciences, Ganeshkhind, Pune 411 007, India
}

Correspondence should be addressed to Shashikala R. Inamdar, pinkisri2001@yahoo.co.in

Received 29 October 2009; Accepted 23 January 2010

Academic Editor: Pi-Wan Cheng

Copyright ( $) 2010$ Nagaraja N. Nagre et al. This is an open access article distributed under the Creative Commons Attribution License, which permits unrestricted use, distribution, and reproduction in any medium, provided the original work is properly cited.

\begin{abstract}
Ophthalmic mycoses caused by infectious fungi are being recognized as a serious concern since they lead to total blindness. Cephalosporium is one amongst several opportunistic fungal species implicated in ophthalmic infections leading to mycotic keratitis. A mitogenic lectin has been purified from the mycelia of fungus Cephalosporium, isolated from the corneal smears of a keratitis patient. Cephalosporium lectin (CSL) is a tetramer with subunit mass of $14 \mathrm{kDa}$, agglutinates human A, B, and O erythrocytes, and exhibits high affinity for mucin compared to fetuin and asialofetuin but does not bind to simple sugars indicating its complex sugar specificity. CSL showed strong binding to normal human peripheral blood mononuclear cells (PBMCs) to elicit mitogenic activity. The sugar specificity of the lectin and its interaction with PBMCs to exhibit mitogenic effect indicate its possible role in adhesion and infection process of Cephalosporium.
\end{abstract}

\section{Introduction}

Ophthalmic infections caused by fungi rather than bacteria are of serious concern in many developing countries as they lead to blindness. Ocular fungal infections referred to as ophthalmic mycoses are leading to keratitis of the cornea [1]. Several fungal species responsible for mycotic keratitis and other forms of eye infections have been reviewed recently $[2,3]$. Fusarium and Cephalosporium (Acremonium) are wide spread fungal species that belong to hyaline filamentous group which are implicated for ophthalmic mycoses [3]. The key factors involved in the pathogenesis of the mycotic keratitis include adherence, invasiveness, morphogenesis, and toxigenicity [4]. Fungal lectins are gaining importance as they are implicated in the process of specific recognition between fungal parasites and their host cells, involving protein-carbohydrate interactions leading to infection [5]. Lectins constitute a heterogeneous group of proteins of nonimmune origin with noncatalytic binding sites capable of recognizing and binding reversibly to specific carbohydrate moieties [6]. Although several reports are available on the lectins from higher fungi [7], very few lectins from animal and plant pathogenic fungi are reported $[5,8-$ 13]. Further, fungal lectins are drawing greater attention as many of them exhibit interesting physiological effects such as lymphomitogenic activity, immunomodulatory effect, suppression of cell proliferation, and antitumor activity [14].

The present paper reports the purification, characterization, and mitogenic activity towards human PBMCs of a lectin from Cephalosporium, a pathogenic fungus, isolated from the infected eye of a keratitis patient.

\section{Materials and Methods}

2.1. Fungal Culture. The fungus was isolated from the corneal smears of a female patient aged 48 years with fungal keratitis. The corneal scrapings were inoculated on Sabourd's dextrose agar (SDA) slants and the stock culture was maintained on SDA slants. Cephalosporium cultures were grown in 500-ml Erlenmeyer flasks containing $100 \mathrm{ml}$ 
Byrde's liquid synthetic media $\left(0.696 \mathrm{~g} \mathrm{KH}_{2} \mathrm{PO}_{4}, 0.149 \mathrm{~g}\right.$ $\mathrm{KCl}, 0.008 \mathrm{~g} \mathrm{ZnSO}_{4} \cdot 2 \mathrm{H}_{2} \mathrm{O}, 0.2 \mathrm{~g} \mathrm{MgSO}_{4}, 0.2 \mathrm{~g} \mathrm{FeSO}_{4}, 0.006 \mathrm{~g}$ $\mathrm{MnSO}_{4}$, and $1 \mathrm{~g} \mathrm{NH}_{4} \mathrm{NO}_{3}$ per liter of distilled water) with $2 \%$ dextrose and incubated at room temperature under stationary conditions [15]. After 10 days, the mycelial mat was harvested and washed with distilled water on cheese cloth. The mycelial mass was subsequently freeze dried and powdered in a glass mortar, and the fine powder was stored at $-20^{\circ} \mathrm{C}$ and used for the purification of lectin.

2.2. Materials. Mucin (porcine stomach, type III), fetuin (fetal calf serum), PHA-L, Histopaque 1077, and fine sugars used in hapten inhibition studies were purchased from Sigma Chemical Co., St. Louis, USA. Sepharose 4B was obtained from Pharmacia Fine Chemicals, Uppsala, Sweden. Asialofetuin was prepared as described by Spiro and Bhoyroo [16]. Asialofetuin-Sepharose 4B, affinity matrix, was prepared by coupling asialofetuin to cyanogen bromideactivated Sepharose $4 \mathrm{~B}$ according to the method of March [17]. Tritiated thymidine was procured from BRIT (Board of Radiation and Isotope Technology), India. The tissue culture flasks and 96 well plates were procured from NUNC (Denmark). Human blood samples were obtained from Health Center, Karnatak University, Dharwad, India, with approval from Institutional Review Board. All other chemicals used were of analytical reagent grade.

2.3. Isolation and Purification of CSL. Dried Cephalosporium mycelial powder was homogenized in $50 \mathrm{ml}(1: 50 \mathrm{w} / \mathrm{v})$ of $50 \mathrm{mM}$ sodium phosphate buffer, $\mathrm{pH} 7.2$, containing $154 \mathrm{mM} \mathrm{NaCl}$ (PBS) for 5 minutes and stirred overnight at $4^{\circ} \mathrm{C}$. The extract was centrifuged $(9500 \mathrm{xg}$ ) for 30 minutes at $4^{\circ} \mathrm{C}$. The resulting supernatant was membrane filtered $(0.45 \mu \mathrm{m})$ and used for the purification of the lectin. The crude extract was subjected to affinity chromatography on asialofetuin-Sepharose $4 \mathrm{~B}$ column $(10 \times 1.3 \mathrm{~cm})$ that had been equilibrated with $\mathrm{PBS}$ and $3 \mathrm{ml}$ fractions were collected at a flow rate of $15 \mathrm{ml} / \mathrm{hr}$. The washing of the column with PBS was continued, until the absorbance of the eluting fractions reads zero at $280 \mathrm{~nm}$ (double beam spectrophotometer, Hitachi 2800). The bound lectin was eluted with glycine- $\mathrm{HCl}$ buffer $(100 \mathrm{mM}, \mathrm{pH} 2.0)$ containing $500 \mathrm{mM} \mathrm{NaCl}$. Fractions containing lectin activity were pooled and dialyzed extensively against PBS and stored at $-20^{\circ} \mathrm{C}$ for further studies.

\subsection{Hemagglutination Assay and Hapten Inhibition Studies.} Hemagglutination activity of CSL during various stages of purification was determined by the serial twofold dilution method using trypsinized human erythrocytes in 96 well, "U" bottom micro titer plates [18]. The highest dilution of the extract causing visible hemagglutination was regarded as the titre and the minimum concentration of the protein was required for agglutination (MCA) as one unit of hemagglutinating activity. The specific hemagglutination activity was expressed as unit $\mathrm{mg}^{-1}$ protein. The sugar specificity of the purified lectin was determined by a hapten inhibition assay. Inhibition assays were carried out by incubating the lectin sample (with hemagglutinating titre of 4) with serially diluted sugar/glycoprotein prior to the addition of erythrocytes in a total volume of $50 \mu \mathrm{l}$, and the hemagglutination was visually observed. The minimum inhibitory concentration of the sugar/glycoprotein was taken as the inhibitory titre of the hapten.

Protein concentrations were determined routinely by Lowry's method [19] and total sugar content of the lectin was estimated by phenol-sulfuric acid method [20].

2.5. Molecular Mass Estimation. The molecular mass of the purified lectin was determined by SDS-PAGE in $15 \%$ gel, according to the method of Laemmli [21] and by gel filtration chromatography on a superdex G-75 column $(1.5 \times 80 \mathrm{~cm}$, in PBS) precalibrated with standard proteins of known molecular weight.

2.6. Binding of CSL to Human PBMCs. Human peripheral blood mononuclear cells (PBMCs) were isolated from the blood of healthy donors by density gradient using Histopaque-1077 (Sigma) and resuspended in complete medium (RPMI $1640+10 \%$ FCS). Fluorescein isothiocyanate-conjugated CSL (FITC-CSL) required for flow cytometry was prepared using the protocol of Goldman [22]. The binding of CSL to PBMCs was determined by flow cytometry. Cells $\left(1 \times 10^{5}\right)$ were incubated with FITC-CSL $(2 \mu \mathrm{g} / 100 \mu \mathrm{l})$ for 1 hour on ice and were washed thoroughly with $50 \mathrm{mM}$ PBS and then fixed with $2 \%$ freshly prepared paraformaldehyde. Data were acquired for 10,000 events using an FACS Vantage (Becton Dickson) equipped with a $488 \mathrm{~nm}$ argon laser and analyzed with Cellquest-pro software for determining $\%$ positivity and mean fluorescence intensity (MFI). Unstained cells that had been processed similarly were used as negative control.

Receptor-mediated CSL binding to PBMCs was determined by preincubating FITC-CSL with mucin, fetuin and asialofetuin $(100 \mu \mathrm{g} / \mathrm{ml})$ for 1 hour at room temperature. This lectin-sugar complex was added to the PBMCs preparation and analyzed by flow cytometry.

2.7. Mitogenic Activity by Tritiated Thymidine Incorporation Assay. Freshly isolated PBMCs were suspended in RPMI1640 containing $10 \%$ FCS and $1 \times 10^{5}$ cells/ $100 \mu \mathrm{l} /$ well were plated in 96 well tissue culture plate (NUNC, Denmark) and incubated with CSL concentration ranging from $0.625 \mu \mathrm{g} / \mathrm{ml}$ to $10 \mu \mathrm{g} / \mathrm{ml}$ for 72 hours at $37^{\circ} \mathrm{C}$ in $5 \% \mathrm{CO}_{2}$. PBMCs stimulated with PHA-L $(0.156 \mu \mathrm{g} / \mathrm{ml}$ to $2.5 \mu \mathrm{g} / \mathrm{ml}$, Sigma Chemicals) were used as positive control. Cells were pulsed with tritiated thymidine $(1 \mu \mathrm{Ci} /$ well, BRIT, India) 18 hour prior to harvesting and incorporation was measured as counts per minute (CPM).

2.8. Statistical Analysis. Statistical analysis was performed using student's $t$-test and Mann-Whitney rank sum test. A $P$-value $<.05$ was considered to be statistically significant. 
TABLE 1: Purification of CSL from mycelial extract.

\begin{tabular}{lcccccccc}
\hline Sample & $\begin{array}{c}\text { Volume } \\
(\mathrm{ml})\end{array}$ & $\begin{array}{c}\text { Protein } \\
(\mathrm{mg})\end{array}$ & $\begin{array}{c}\text { Sugar } \\
(\mathrm{mg})\end{array}$ & $\begin{array}{c}\text { MCA }^{\mathrm{a}} \\
(\mu \mathrm{g})\end{array}$ & $\begin{array}{c}\text { Specific activity } \\
(\text { units })\end{array}$ & $\begin{array}{c}\text { Total activity } \\
(\text { units })\end{array}$ & $\begin{array}{c}\text { Fold } \\
\text { purification }\end{array}$ & $\begin{array}{c}\text { Recovery of } \\
\text { activity }(\%)\end{array}$ \\
\hline Original crude extract & 41.0 & 30.053 & 22.96 & 1.145 & $0.087 \times 10^{4}$ & $2.61 \times 10^{4}$ & - & 100 \\
Affinity purified & 7.5 & 0.410 & $\mathrm{ND}^{\mathrm{b}}$ & 0.021 & $4.76 \times 10^{4}$ & $1.95 \times 10^{4}$ & 54.71 & 74.71 \\
\hline
\end{tabular}

a -Minimum concentration of protein required to agglutinate erythrocytes used.

b-Not detected by phenol-sulfuric acid method.

${ }^{c}$-Specific activity: hemagglutinating activity $\mathrm{mg}^{-1}$ protein.

d-Total activity: hemagglutinating activity of lectin in total protein.

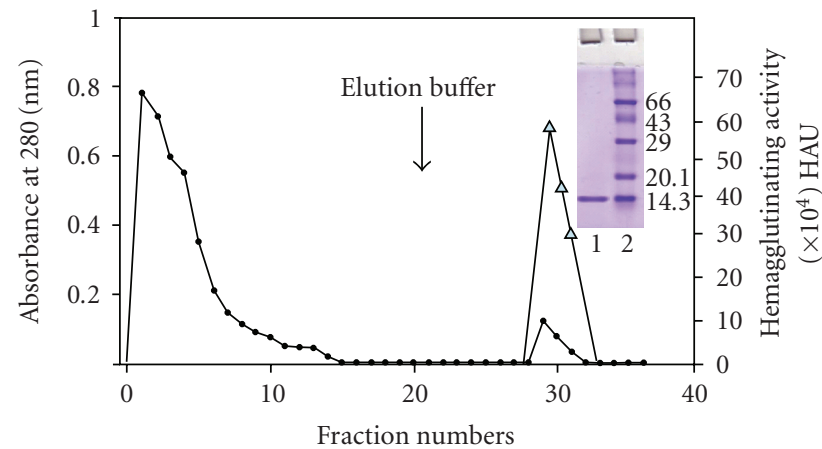

FIgURE 1: Affinity purification of Cephalosporium lectin on asialofetuin-Sepharose 4B column. Crude extract was passed through affinity column, equilibrated in PBS, and the bound lectin was eluted with elution buffer. Fractions of $3.0 \mathrm{ml}$ were collected at a flow rate of $15 \mathrm{ml} / \mathrm{hr}$. $\rightarrow$ Absorbance at $280 \mathrm{~nm},-\triangle-$ Hemagglutinating activity. Inset- SDS-PAGE of affinity purified CSL in $15 \%$ gel. The purified lectin $(30 \mu \mathrm{g})$ is indicated in lane 1 and lane 2 contains standard molecular weight markers. The gel was stained with Coomassie brilliant blue.

\section{Results}

3.1. Isolation and Purification of the Lectin from the Mycelium of Cephalosporium. The lectin was purified to homogeneity in a single step by affinity chromatography on asialofetuinSepharose 4B column (Figure 1). The fold purification and the total $\%$ recovery of the purified lectin from $1 \mathrm{~g}$ of the dry mycelial powder are summarized in Table 1; the minimum concentration of the protein required for agglutination (MCA) was found to be $1.145 \mu \mathrm{g}$ for the crude extract and $0.021 \mu \mathrm{g}$ for the purified lectin. The eluted lectin was found to be homogenous as revealed by single band on SDS-PAGE in 15\% gel (Figure 1, Inset). Subunit molecular mass of $14 \mathrm{kDa}$ was estimated for the lectin by SDS-PAGE, whereas molecular mass of $57 \mathrm{kDa}$ was estimated by gel filtration chromatography (Figure 2), suggesting tetrameric nature of the lectin. Purified CSL agglutinated the human erythrocytes of all blood groups, indicating that it has a blood group nonspecific nature. Hapten inhibition studies showed that the hemagglutinating activity of CSL was inhibited by mucin, fetuin, and asialofetuin, with mucin being the most potent inhibitor with minimum inhibitory concentration (MIC) of $0.785 \mu \mathrm{g} / 50 \mu \mathrm{l}$ (Table 2).

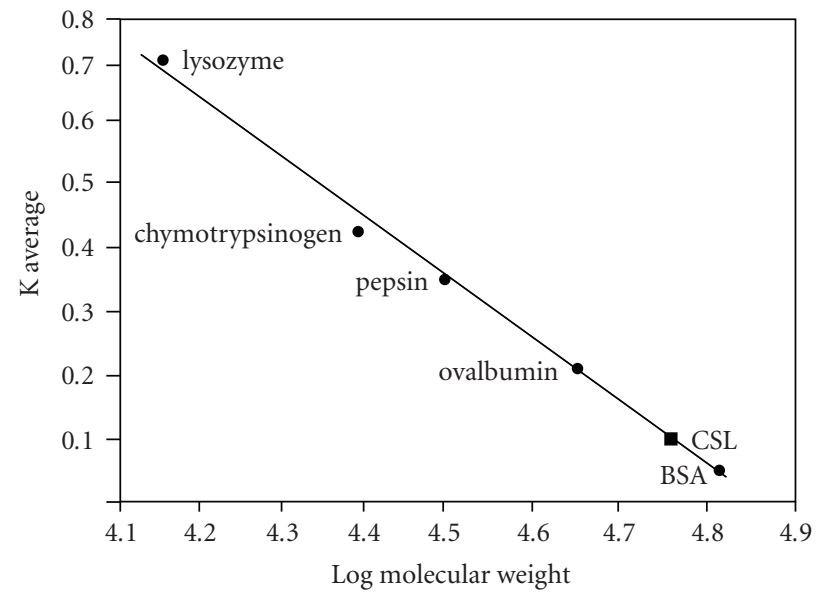

FIGURE 2: Calibration curve for the estimation of molecular weight of CSL by gel filtration chromatography. $X$-axis represents the $\log$ molecular weight and $Y$-axis represents $\mathrm{K}$ average, marker proteins; BSA $(66 \mathrm{kDa})$, ovalbumin $(45 \mathrm{kDa})$, pepsin $(34.7 \mathrm{kDa})$, chymotrypsinogen $(25.6 \mathrm{kDa})$ and lysozyme $(14.3 \mathrm{kDa})$.

3.2. Binding of CSL to Human PBMCs. To study the interaction of CSL with PBMCs, cells were stained with FITCCSL and its binding was analysed by flow cytometry. As depicted in Figure 3(a), 99.62\% of the cells were found to be positive for CSL binding, with mean fluorescence intensity (MFI) of 411.27, in comparison with control unstained cells which were set to $1 \%$ positivity and the MFI of this $1 \%$ cells was 76.89. The receptor-mediated lectin binding to PBMCs was confirmed by studying the binding of CSL after preincubation of the lectin with different competing glycoconjugates or haptens. Flow cytometry histograms of CSL binding to PBMCs before and after blocking with mucin, fetuin, and asialofetuin are presented in Figures 3(a), 3(b), 3(c), and $3(\mathrm{~d})$, respectively. Mucin at $100 \mu \mathrm{g} / \mathrm{ml}$ concentration was the most effective inhibitor of CSL followed by fetuin and asialofetuin at $100 \mu \mathrm{g} / \mathrm{ml}$.

3.3. Mitogenic Activity of CSL. Mitogenic effect of CSL on human PBMCs was determined by tritiated thymidine incorporation assay. CSL stimulated the uptake of thymidine by human PBMCs in a dose-dependent manner, with maximum incorporation occurring at $10 \mu \mathrm{g} / \mathrm{ml}$ of 
TABLE 2: Hapten inhibition studies with purified CSL.

\begin{tabular}{lc}
\hline Glycoprotein & Minimum concentration required for inhibition, $\mathrm{MIC}(\mu \mathrm{g} / 50 \mu \mathrm{l})$ \\
\hline Mucin (from porcine stomach) & 0.785 \\
Fetuin & 6.25 \\
Asialofetuin & 12.5 \\
\hline
\end{tabular}

*D-(+)-Galactose, D-(+)-Glucose, D-(+)-Mannose, D-(+)-Arabinose, D-(+)-Fucose, L-(-)-Fucose, $\beta$-D(+)-Glucose, 2-Deoxy-D-glucose, $\alpha$-L-Rhamnose, 1-Amino-1-deoxy- $\beta$-D-glucose, N-Acetyl-D-galactosamine, N-Acetyl-D-glucosamine, N-Acetyl- $\beta$-D-mannosamine, Methyl- $\alpha$-D-mannopyranoside, Methyl- $\alpha$-D-galactopyranoside, Methyl- $\beta$-D-galactopyranoside, Methyl- $\beta$-D-glucopyranoside, 4Aminophenyl $\beta$-D-galactopyranoside, 4-Aminophenyl $\beta$-D-glucopyranoside, $\mathrm{N}$-Acetyl neuraminic acid, $\beta$-D-Galactose(1-4) $\beta$-Dglucose ( $\beta$-Lactulose), $\beta$-D-Glucose(1-4)-D-glucose (cellobiose), $6-\alpha$-D-Galactopyranosyl-D-glucopyranose (melibiose), and O- $\alpha$-DGalactopyranosyl-(1-6)- $\alpha$-D-glucopyranosyl- $\beta$-D-fructofuranoside (raffinose) did not inhibit the lectin activity up to concentrations of $200 \mathrm{mM}$. Also, ovalbumin $(2 \mathrm{mg} / \mathrm{ml})$, and the plant polysaccharides guar gum $(1 \mathrm{mg} / \mathrm{ml})$, gum acacia $(10 \mathrm{mg} / \mathrm{ml})$, were not inhibitory.

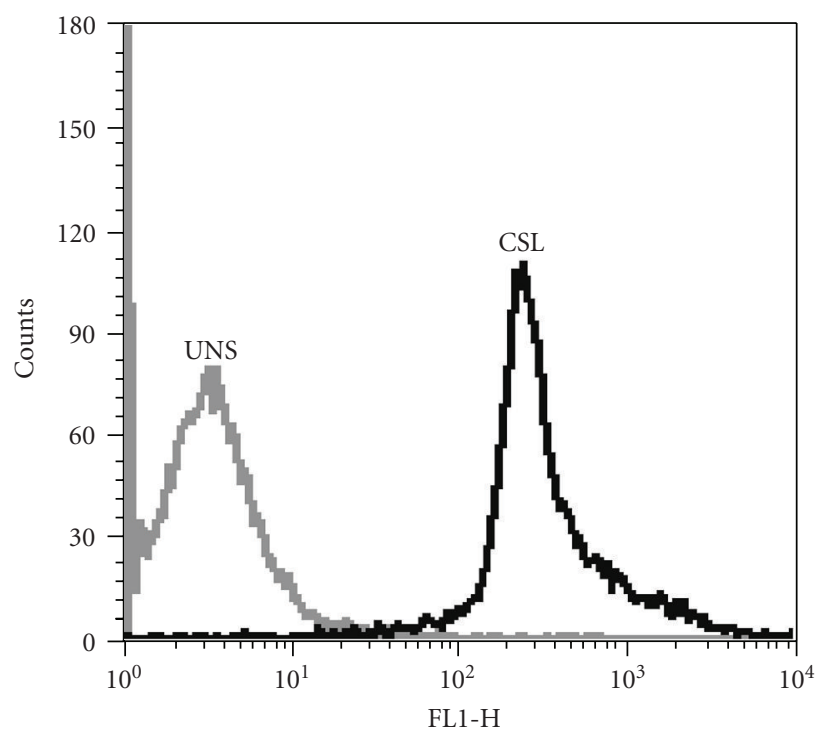

(a)

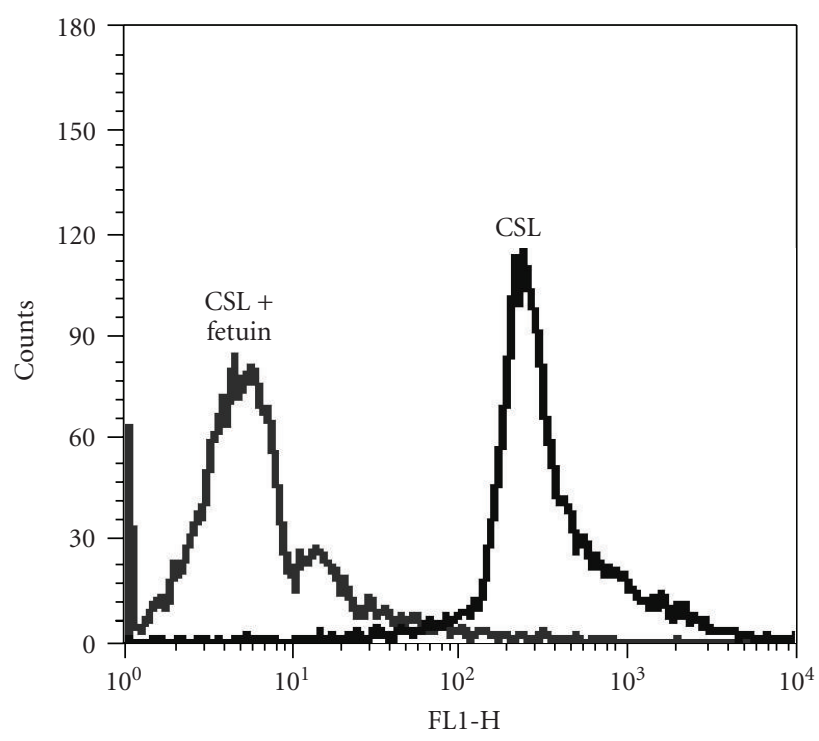

(c)

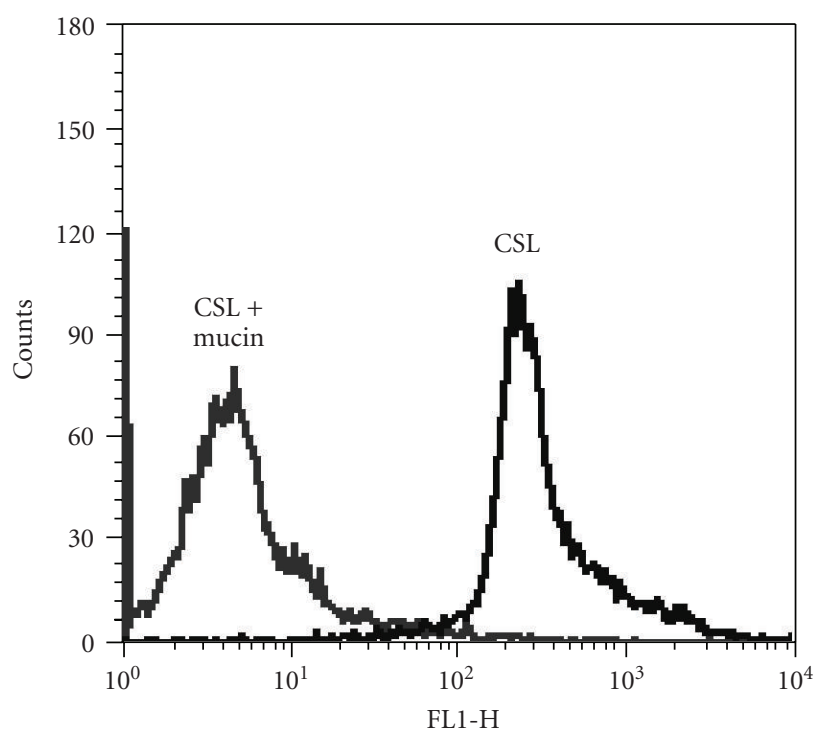

(b)

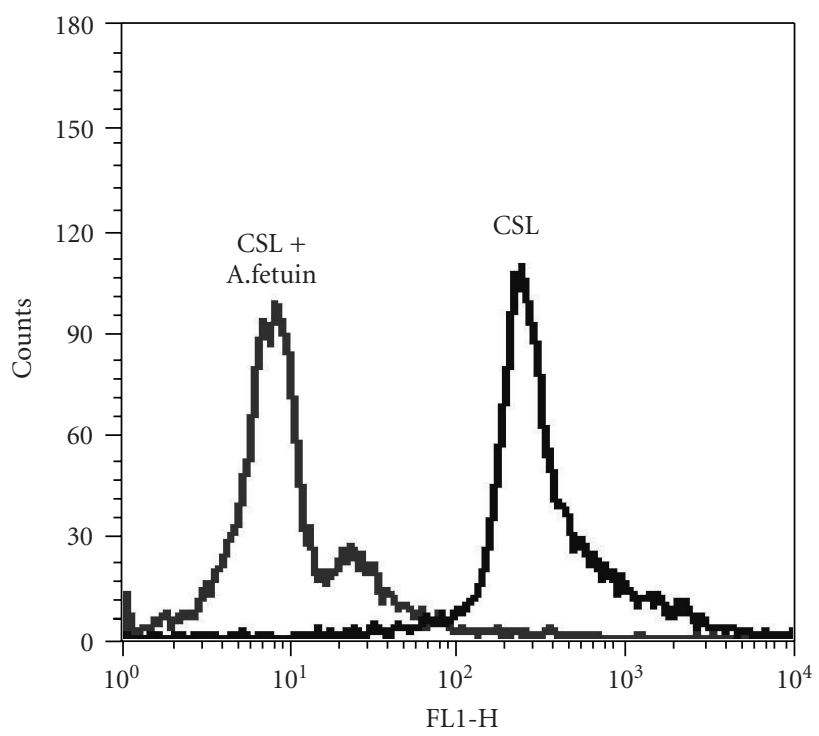

(d)

FIGURE 3: Binding of CSL to human PBMCs and inhibition of binding with competing glycoconjugates. PBMCs were stained with FITClabeled CSL and subjected to flow cytometric analysis. $X$-axis, FL1-H on a log scale represents the fluorescence intensity of cells stained with FITC labeled CSL. $Y$-axis represents cell number. (a) The histoplot shows profiles of the unstained cells (UNS) and cells stained with FITC-labeled CSL (CSL). Profiles of cells stained with FITC-labeled CSL preincubated with different haptens are indicated in (b, $\mathrm{c}$ and d). 


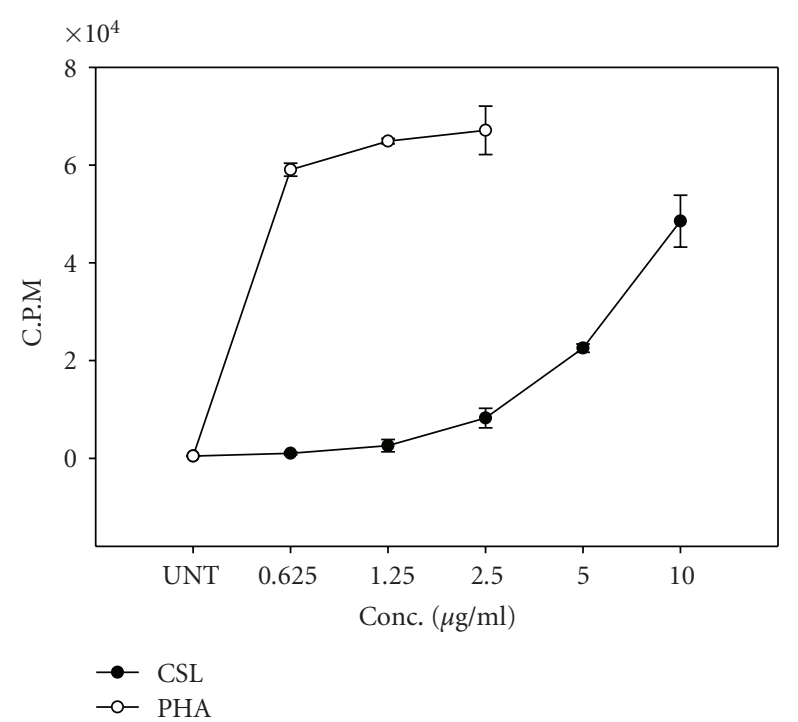

FIgUre 4: Mitogenic activity of CSL. PBMCs were isolated from blood of healthy donors and exposed to serial concentrations of CSL $(0.625-10 \mu \mathrm{g} / \mathrm{ml})$ and PHA-L $(0.16-2.5 \mu \mathrm{g} / \mathrm{ml})$ for 72 hours and proliferation was measured by tritiated thymidine incorporation assay as counts per minute (CPM). The data are presented as mean $\pm \mathrm{SE}$ of four independent experiments done in triplicates.

the different doses tested $(0.625-10 \mu \mathrm{g} / \mathrm{ml})$, whereas PHA$\mathrm{L}$, a positive control exhibited maximum proliferation at $1.25 \mu \mathrm{g} / \mathrm{ml}$ (Figure 4).

\section{Discussion}

In the present study, the lectin from human pathogenic fungus Cephalosporium isolated from mycotic keratitis patient was purified to homogeneity in a single step by affinity chromatography on asialo fetuin-Sepharose 4B. CSL, a tetramer, without blood group specificity, has complex sugar specificity and mitogenic activity on human PBMCs. In the past decade, sizeable numbers of fungal lectins are reported and majority of them are from higher fungi, mostly from fruiting bodies of mushrooms [7, 23]. However, very few lectins are known from the mycelia forming lower fungi, particularly the pathogenic fungi, although fungal lectins are implicated in host parasite interactions [5]. There is a growing realization that the fungal lectins like bacterial lectins also play an important role in adhesion and infection process. Several hyaline filamentous fungi are considered as opportunistic human pathogens [3]. Most of these pathogens express surface factors, lectins that mediate binding to extra cellular matrix glycoproteins of host cells. Such a binding would facilitate the fungal adherence and can induce immunomodulatory effect on the host cells. In this regard, the CSL exerts mitogenic activity on human PBMCs. So far, very few lectins from human pathogenic fungi are reported including Candida albicans, Candida glabrata, Histoplasma capsulatum, Aspergillus fumigatus, and Trycophyton rubrum $[5,10,24,25]$. The lectin from $C$. albicans which recognizes Fuc $\alpha 1-2 \mathrm{Gal} \beta$, occurring on all blood group substances of $\mathrm{ABO}$ types, is implicated in the adherence to human buccal epithelial cells [9]. A $32 \mathrm{kDa}$ lectin purified from $A$. fumigatus, with sialic acid specificity is suggested to play an important role in the attachment of conidia to extra cellular matrix components of host cells [10]. A. fumigatus is a known opportunistic pathogen responsible for variety of ophthalmic infections such as dacryocystitis, scleritis and endophthalmitis [3]. An extracellular agglutinin from Trycophyton rubrum, a well-known dermatophyte, has specificity towards sialo oligosaccharides is implicated for the adhesion to host cells [25].

There is no direct evidence available confirming the role of lectins from these pathogens in mediating host parasite interactions and also in their immunomodulatory effects on the host cells. On the contrary, several lectins from higher fungi are known to exert interesting immunomodulatory effects. Lectins from $V$. volvacea and Boletus satanas Lenz exhibit mitogenic effects on human PBMCs [26, 27], whereas Agrocybe cylindracea and Schizophyllum commune exerts mitogenic effect on mouse splenocytes [28, 29]. Some of the mitogenic lectins like those from $V$. volvacea, $F$. velutipes, and Ganoderma lucidum were shown to exhibit immunomodulatory effects [30-32], and such mitogenic lectins have potential applications as important diagnostic and experimental tool to study the various aspects of cell growth and differentiation. The receptor mediated binding of CSL to human PBMCs was clearly demonstrated, as it can be effectively blocked by competing glycoconjugates such as mucin, fetuin and asialofetuin. These results substantiate our observations by hapten inhibition studies that CSL has preferential affinity towards mucin compared to fetuin or asialofetuin. The mitogenic potential of CSL was demonstrated by the observed dose-dependent increase in proliferation of PBMCs.

In summary, the lectin with complex sugar specificity purified from the pathogenic fungus Cephalosporium, which is responsible for ophthalmic mycoses, exhibits mitogenic and hemagglutinating activity. It is one of the few lectins characterized from pathogenic fungi reported and the information provides valuable account for understanding the lectin mediated host-parasite interaction in fungal infections.

\section{Acknowledgments}

Authors thank professor Arunaloke Chakrabarti, Department of Medical Microbiology, National Culture Collection of Pathogenic Fungi (NCCPF), PGIMER, Chandigarh (India) for identification of the fungal culture. This work was supported by a Grant (SR/SO/BB/43/2003) funded by Department of Science and Technology, New Delhi, India.

\section{References}

[1] L. A. Levin, R. Avery, J. W. Shore, J. J. Woog, and A. S. Baker, "The spectrum of orbital aspergillosis: a clinicopathological review," Survey of Ophthalmology, vol. 41, no. 2, pp. 142-154, 1996. 
[2] S. A. Klotz, C. C. Penn, G. J. Negvesky, and S. I. Butrus, "Fungal and parasitic infections of the eye," Clinical Microbiology Reviews, vol. 13, no. 4, pp. 662-685, 2000.

[3] P. A. Thomas, "Current perspectives on ophthalmic mycoses," Clinical Microbiology Reviews, vol. 16, no. 4, pp. 730-797, 2003.

[4] S. Ananthi, T. Chitra, R. Bini, N. V. Prajna, P. Lalitha, and K. Dharmalingam, "Comparative analysis of the tear protein profile in mycotic keratitis patients," Molecular Vision, vol. 14, pp. 500-507, 2008.

[5] M. J. S. Mendes-Giannini, M. L. Taylor, J. B. Bouchara, et al., "Pathogenesis II: fungal responses to host responses: interaction of host cells with fungi," Medical Mycology, vol. 38, pp. 113-123, 2000.

[6] I. J. Goldstein, R. C. Hughes, M. Monsigny, T. Osawa, and N. Sharon, "What should be called a lectin?" Nature, vol. 285, no. 5760, p. 66, 1980.

[7] J. Guillot and G. Konska, "Lectins in higher fungi," Biochemical Systematics and Ecology, vol. 25, no. 3, pp. 203-230, 1997.

[8] I. A. Ceitchley and L. J. Douglas, "Role of glycosides as epithelial cell receptors for Candida albicans," The Journal of General and Applied Microbiology, vol. 133, no. 3, pp. 637-643, 1987.

[9] D. Brassart, A. Woltz, M. Golliard, and J.-R. Neeser, "In vitro inhibition of adhesion of Candida albicans clinical isolates to human buccal epithelial cells by Fuc $\alpha$ 1-2 Gal $\beta$-bearing complex carbohydrates," Infection and Immunity, vol. 59, no. 5, pp. 1605-1613, 1991.

[10] G. Tronchin, K. Esnault, M. Sanchez, G. Larcher, A. MarotLeblond, and J. Bouchara, "Purification and partial characterization of a 32-kilodalton sialic acid specific lectin from Aspargillus fumigatus," Infection and Immunity, vol. 70, no. 12, pp. 6891-6895, 2002.

[11] B. M. Swamy, A. G. Bhat, G. V. Hegde, R. S. Naik, S. Kulkarni, and S. R. Inamdar, "Immunolocalization and functional role of Sclerotium rolfsii lectin in development of fungus by interaction with its endogenous receptor," Glycobiology, vol. 14, no. 11, pp. 951-957, 2004.

[12] D. D. Leonidas, B. M. Swamy, G. N. Hatzopoulos, et al., "Structural basis for the carbohydrate recognition of the Sclerotium rolfsii Lectin," Journal of Molecular Biology, vol. 368, no. 4, pp. 1145-1161, 2007.

[13] J. Bhowal, A. K. Guha, and B. P. Chatterjee, "Purification and molecular characterization of a sialic acid specific lectin from the phytopathogenic fungus Macrophomina phaseolina," Carbohydrate Research, vol. 340, no. 12, pp. 1973-1982, 2005.

[14] G. Konska, "Lectins of higher fungi (macromycetes)-their occurrence, physiological role, and biological activity," International Journal of Medicinal Mushrooms, vol. 8, no. 1, pp. 1930, 2006.

[15] R. J. Byrde, J. F. Harris, and D. Woodcock, "Fungal detoxication, the metabolism of $\omega$-(2- naphthyloxy)- $n$-alkylcarboxylic acids by Aspergillus niger," The Biochemical Journal, vol. 64, no. 1, pp. 154-160, 1956.

[16] R. G. Spiro and V. D. Bhoyroo, "Structure of the Oglycosidically linked carbohydrate units of fetuin," Journal of Biological Chemistry, vol. 249, no. 18, pp. 5704-5717, 1974.

[17] S. C. March, I. Parikh, and P. Cuatrecasas, "A simplified method for cyanogen bromide activation of agarose for affinity chromatography," Analytical Biochemistry, vol. 60, no. 1, pp. 149-152, 1974.

[18] I. E. Liener and E. G. Hill, "The effect of heat treatment on the nutritive value and hemagglutinating activity of soybean oil meal," Journal of Nutrition, vol. 49, pp. 609-620, 1953.
[19] O. H. Lowry, N. J. Rosebrough, A. L. Farr, and R. J. Randall, "Protein measurement with the folin phenol reagent," The Journal of Biological Chemistry, vol. 193, no. 1, pp. 265-275, 1951.

[20] M. Dubois, K. A. Gilles, J. K. Hamilton, P. A. Rebers, and F. Smith, "Colorimetric method for determination of sugars and related substances," Analytical Chemistry, vol. 28, no. 3, pp. 350-356, 1956.

[21] U. K. Laemmli, "Cleavage of structural proteins during the assembly of the head of bacteriophage T4," Nature, vol. 227, no. 5259, pp. 680-685, 1970.

[22] M. Goldman, "Fluorescent antibody methods," in Procedures for Conjugation, pp. 101-161, Academic Press, New York, NY, USA, 1968.

[23] H. Wang, T. B. Ng, and Q. Liu, "Isolation of a new heterodimeric lectin with mitogenic activity from fruiting bodies of the mushroom Agrocybe cylindracea," Life Sciences, vol. 70, no. 8, pp. 877-885, 2002.

[24] B. P. Cormack, N. Ghori, and S. Falkow, "An adhesin of the yeast pathogen Candida glabrata mediating adherence to human epithelial cells," Science, vol. 285, no. 5427, pp. 578$582,1999$.

[25] J. Bhowal, A. Mitra, S. Banerjee, S. Sikdar, A. K. Guha, and B. P. Chatterjee, "Purification and characterization of an extracellular agglutinin from Tricophyton rubrum with specificity towards sialic acid containing glycoconjugates," Indian Journal of Biochemistry and Biophysics, vol. 41, no. 23, pp. 81-88, 2004.

[26] Q.-B. She, T.-B. Ng, and W.-K. Liu, "A novel lectin with potent immunomodulatory activity isolated from both fruiting bodies and cultured mycelia of the edible mushroom Volvariella volvacea," Biochemical and Biophysical Research Communications, vol. 247, no. 1, pp. 106-111, 1998.

[27] F. Licastro, M. C. Morini, O. Kretz, G. Dirheimer, and E. E. Creppy, "Mitogenic activity and immunological properties of bolesatine, a lectin isolated from the mushroom Boletus satanas Lenz," International Journal of Biochemistry, vol. 25, no. 5, pp. 789-792, 1993.

[28] H. Wang, T. B. Ng, and Q. Liu, "Isolation of a new heterodimeric lectin with mitogenic activity from fruiting bodies of the mushroom Agrocybe cylindracea," Life Sciences, vol. 70, no. 8, pp. 877-885, 2002.

[29] C. H. Han, Q. H. Liu, T. B. Ng, and H. X. Wang, "A novel homodimeric lactose binding lectin from the edible split medicinal mushroom Schizophyllum commune," Biochemical and Biophysical Research Communications, vol. 336, pp. 252257, 2005.

[30] H.-C. Hsu, C.-I. Hsu, R.-H. Lin, C.-L. Kao, and J.-Y. Lin, "A new fungal immunomodulatory protein isolated from Volvariella volvacea," Biochemical Journal, vol. 323, no. 2, pp. 557-565, 1997.

[31] J. L. Ko, C. I. Hsu, R. H. Lin, C. L. Kao, and J. Y. Lin, "A new fungal immunomodulatory protein, FIP-fve isolated from the edible mushroom, Flammulina velutipes and its complete amino acid sequence," European Journal of Biochemistry, vol. 228, no. 2, pp. 244-249, 1995.

[32] W. H. Lin, C. H. Hung, C. I. Hsu, and J. Y. Lin, "Dimerization of the N-terminal amphipathic $\alpha$-helix domain of the fungal immunomodulatory protein from Ganoderma tsugae (Fipgts) defined by a yeast two-hybrid system and site-directed mutagenesis," The Journal of Biological Chemistry, vol. 272, no. 32, pp. 20044-20048, 1997. 

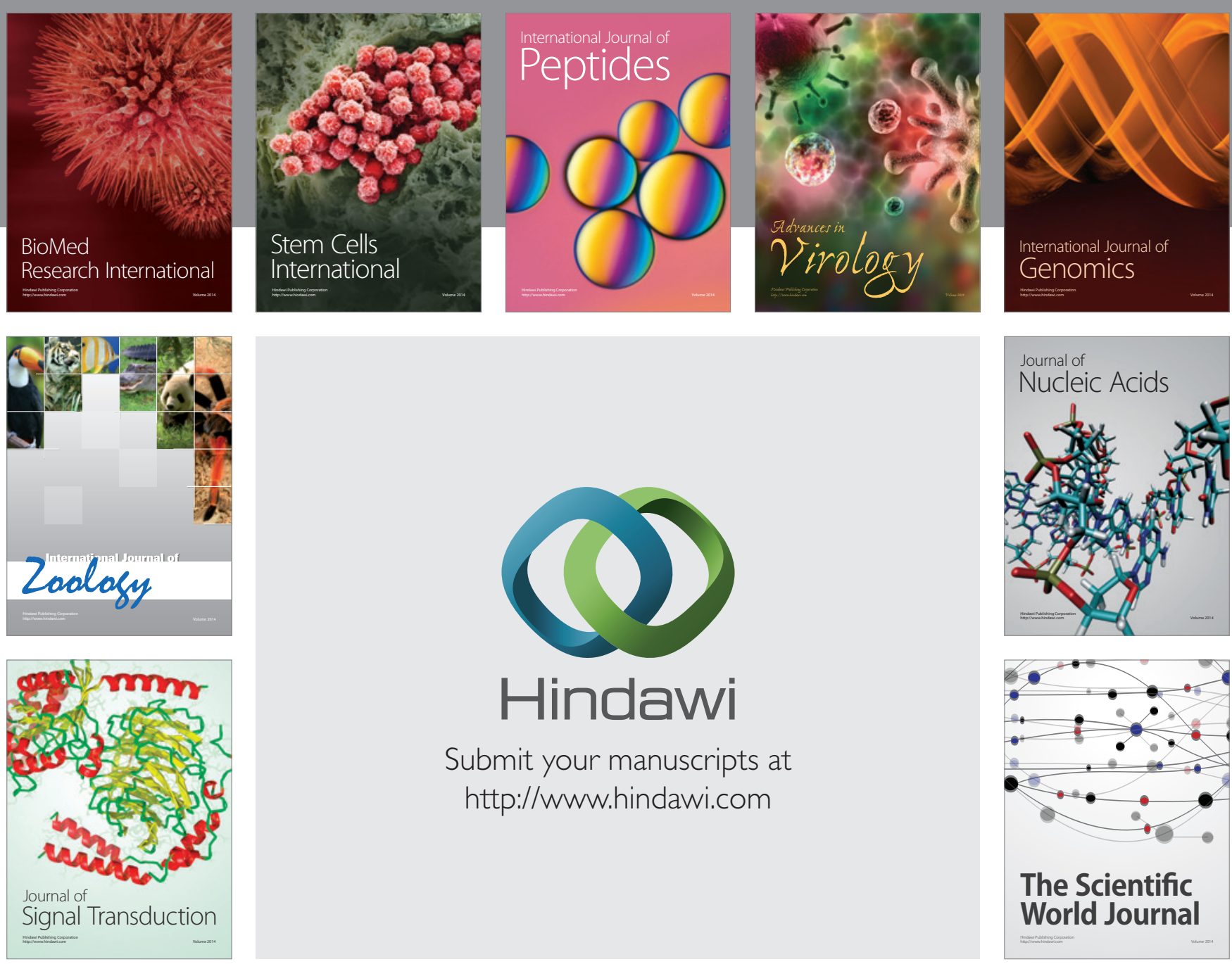

Submit your manuscripts at

http://www.hindawi.com
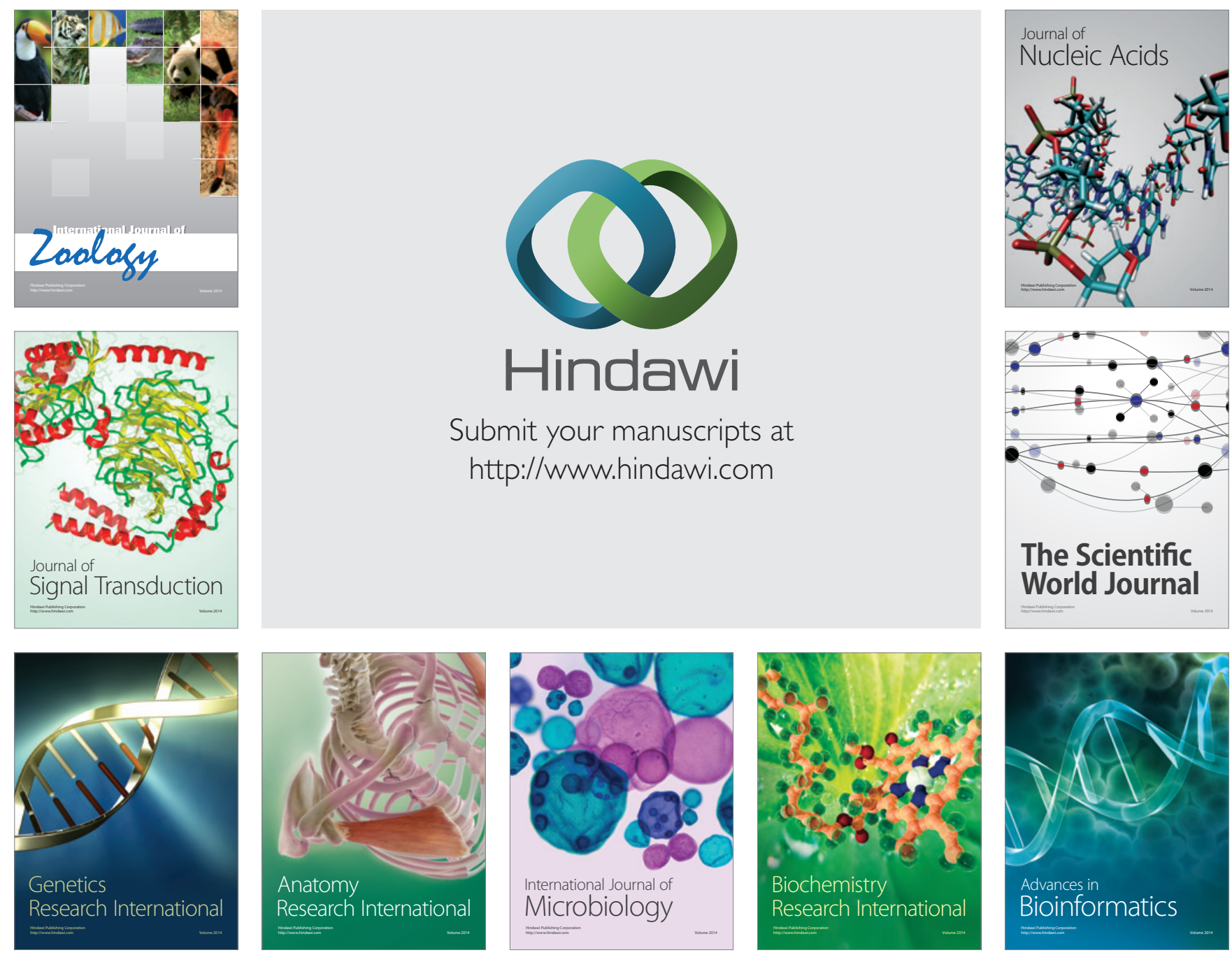

The Scientific World Journal
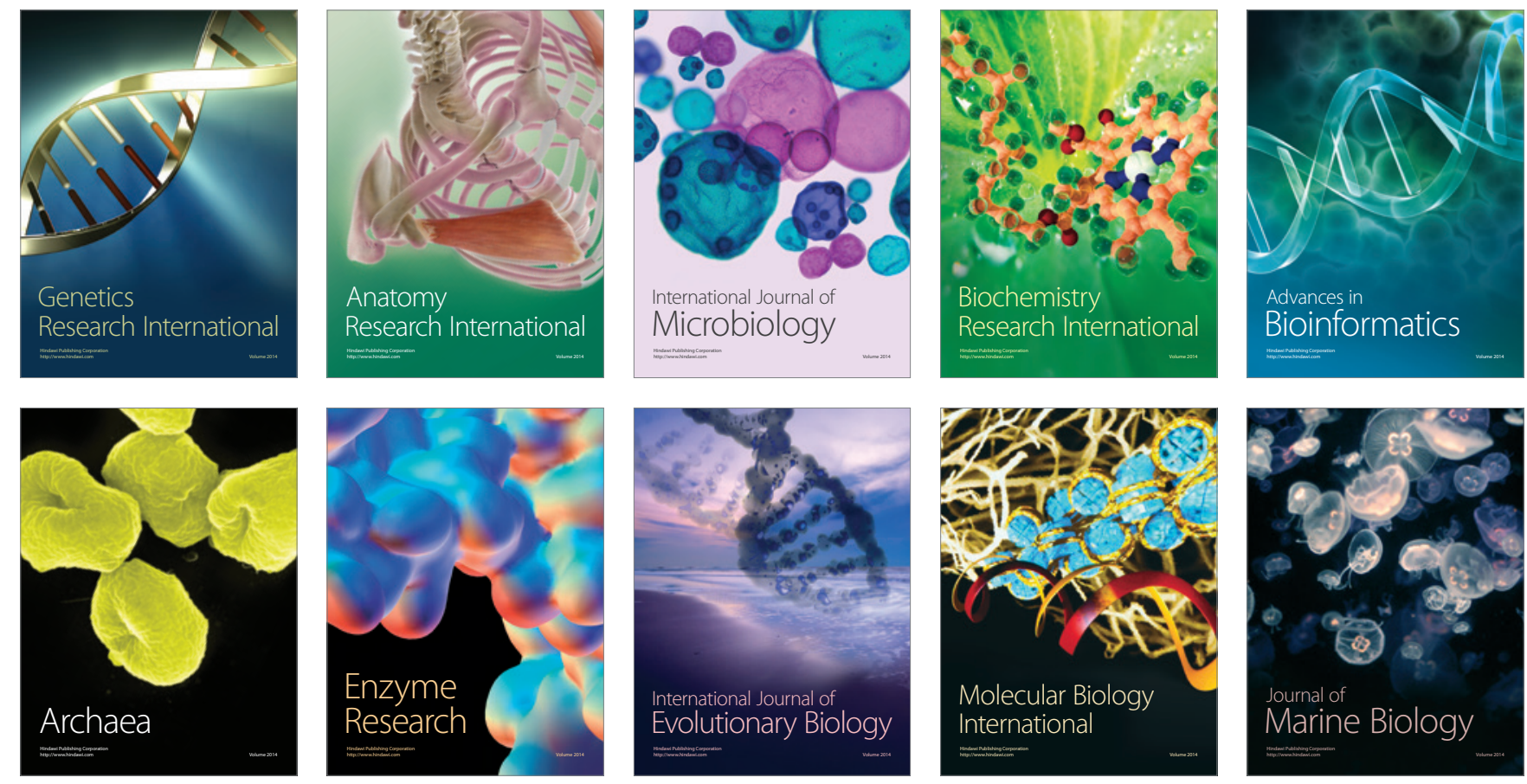